\title{
透析患者における上腕一足首脈波伝播速度の 経年的変化に及ぼすエイコサペンタエン酸の影響
}

\author{
田中男山本雅俊平山順朗中西努 \\ 翡翠会つるまエキチカじんクリニック
}

キーワード：透析，脈波速度，baPWV， EPA，エイコサペンタエン酸

〈要旨〉

【目的】血液透析患者に対する高純度エイコサペンタエン酸エチル（ethyl-eicosapentaenoic acid：EPA-E）製剂 の動脈硬化進展抑制作用を上腕一足首の脈波伝播速度（baPWV）により検討した.【方法】平成 16 年から平成 22 年までに当院を受診した血液透析患者 173 例を対象に，(1) 平成 22 年度の患者背景別 baPWV 值, (2) EPA-E 投与 群と非投与群の baPWV 值の比較（1 年間および最長 6 年間の経年的推移）をレトロスペクティブに検討した.【結 果】患者背景別の baPWV 值は, 糖尿病または高血圧合併例, 脳血管疾患合併例において統計学的に差は認められ なかったが高值であり, 虚血性心疾患合併例においては有意に高かった. 1 年間における baPWV の平均值の変化 は, EPA-E 非投与群では統計学的に差は認められなかったが上昇した一方 $(+3.0 \%)$, EPA-E 投与群では変化がみ られなかった $(+0.2 \%)$. baPWV の経年的な平均変化率は, EPA-E 非投与群では有意な上昇 $(p<0.05)$ がみられ たが, EPA-E 投与群では変化がみられなかった.【結論】 EPA-E の投与によって血液透析患者の経年的な baPWV の上昇が抑制される可能性が示唆され，EPA-E は透析患者の心血管イベント発症抑制に有益である可能性がある と考えられた.

\section{Effects of eicosapentaenoic acid on yearly brachial-ankle pulse wave velocity changes in dialysis patients}

Rikio Tanaka, Masatoshi Yamamoto, Nobuaki Hirayama and Tsutomu Nakanishi

Hisuikai Tsurumaekichikajinclinic

Key words : dialysis, pulse wave velocity, brachial-ankle pulse wave velocity, eicosapentaenoic acid

〈Abstract〉

【Objectives】 The inhibitory action of a high-purity eicosapentaenoic acid ethyl ester (EPA-E) preparation on the progression of arterial sclerosis in hemodialysis patients was investigated employing brachial-ankle pulse wave velocity (baPWV) data. 【Methods】 Among 173 hemodialysis patients consulting our institution between 2004 and 2010, (1) baPWV values in 2010 as classified by patient backgrounds and (2) comparison of baPWV values in groups with and without EPA-E treatment (change in one year and yearly changes for up to six years) were examined retrospectively. 【Results】 The baPWV values as classified by patient backgrounds were high in cases complicated by diabetes mellitus or hypertension and those with cerebrovascular disease (not significant), and the values were significantly higher in cases with ischemic heart disease. Regarding changes in the mean baPWV in one year, an increased value $(+3.0 \%)$ was seen in the group without EPA-E treatment (not significant), while there was no change in the group with EPA-E treatment $(+0.2 \%)$. The mean yearly change rate of baPWV exhibited a significant increase $(p<0.05)$ in the group without EPA-E treatment, while there was no change in the group with EPA-E treatment. 【Conclusions】 The possibility that yearly baPWV increases in hemodialysis patients can be inhibited by the administration of EPA-E was revealed, and EPA-E was also suggested to be beneficial for inhibiting the onset of cardiovascular events in dialysis patients.

田中 力男 翡翠会つるまエキチカじんクリニック⿸广 242-0004 神奈川県大和市鶴間 2-1-24

Rikio Tanaka Tel : 046-271-0808 Fax : 046-271-0888

〔受付日：2011 年 12 月 22 日, 受理日：2012 年 5 月 2 日〕 


\section{緒言}

血液透析患者の数は年々増加しており，心血管病に よる死亡が問題になっている. 日本透析医学会の 2009 年末のデータによると, 慢性透析患者は 290,675 例であり，人口 100 万人あたりの透析患者数は $2,279.6$ 人である。また透析患者の死亡原因の上位は 心不全や脳血管障害, 心筋梗塞といった心血管病であ る.

この心血管病による死亡は透析患者においては健常 人よりも高率にみられるといわれている。海外の前向 きコホート試験の結果によると，透析患者の心血管病 死亡率は健常人の約 10 倍であり, 透析患者の心血管 病による死亡率は全死亡の内の約 $40 \%$ であるとい $j^{1 \sim 3)}$

このような心血管死に至る原因として，透析患者に おいて動脈硬化が高度に認められることがあげられて いる ${ }^{4)}$. 動脈硬化の指標である大動脈の脈波伝播速度 (pulse wave velocity：PWV) は透析患者では健常者 に比較し有意に大きいとの報告もある ${ }^{5 \sim 7)}$. そのため, 動脈硬化の状態を把握し, 進展を抑制することが透析 患者における心血管死の予防につながると考えられ る.

動脈硬化の進展を抑制し心血管イベント発症を抑制 する薬剤の一つとして, eicosapentaenoic acid (EPA) が注目されている. EPA は魚類に多く含まれる $\omega 3$ 系多価不飽和脂肪酸の一つであり，魚食頻度の高い日 本人においても食事による魚類の摂取や $\omega 3$ 系多価不 飽和脂肪酸の攝取が多いほど, 心血管イベント発症が 少ないという前向きコホート試験が発表されてい $ろ^{8)}$.

また， $\omega 3$ 系多価不飽和脂肪酸による心血管イベン 卜抑制効果を検討した介入試験も行われている. イ夕 リアで行われた Gruppo Italiano per lo Studio della Sopravvivenza nell' Infarto miocardico Prevenzione （GISSI-P）試験では，急性心筋梗塞患者に対する $\omega 3$ 系多価不飽和脂肪酸の心血管イベント抑制効果が示さ れ ${ }^{9)}$, GISSI-Heart Failure 試験においては慢性心不全 患者に対する $\omega 3$ 系多価不飽和脂肪酸の予後改善効果 が示されている ${ }^{10)}$. また, 日本人の高コレステロール 血症患者約 19,000 例を対象とし, ethyl-eicosapentaenoic acid : EPA-E（エパデール ${ }^{\circledR}$ ) の冠動脈イベン 卜抑制効果を検討した Japan EPA Lipid Intervention Study（JELIS）試験においては，EPA-E 投与群では 冠動脈イベント発症リスクが 19\%低下したと報告さ
れている ${ }^{11)}$ 。さらに，閉塞性動脈硬化症患者を対象と した JELIS サブ解析では EPA-E 投与群において冠 動脈イベント発症が有意に低下していたことも報告さ れている12).

このように, $\mathrm{EPA}$ 等の $\omega 3$ 系多価不飽和脂肪酸は心 血管イベントの発症を抑制することが報告されている が， $\omega 3$ 系多価不飽和脂肪酸の捸取量が多く血中濃度 が高いと, 動脈硬化の進展が軽度であるとする疫学調 查 ${ }^{13)}$ が報告されており, $\omega 3$ 系多価不飽和脂肪酸は動 脈硬化の進展とも関連が深いと考えられている．透析 患者では血中あるいは赤血球膜の $\omega 3$ 系多価不飽和脂

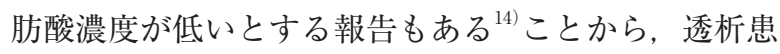
者に対して EPA を投与することは動脈硬化抑制の観 点から合理的であると考えられる。実際に，EPA-E の投与により頸動脈内膜中膜複合体肥厚度 (intimamedia thickness : IMT) やPWV が透析患者において 低下したとの報告もあり ${ }^{15,16)}$ ＥPA の投与によって透 析患者の動脈硬化進展抑制，ひいては心血管病の発症 抑制効果が期待される.

これらの背景から今回, 透析患者における長期的な 動脈硬化の進展に対する EPA-E の抑制効果を, 非侵 襲的かつ簡便に測定可能な指標である baPWV を指標 としてレトロスペクティブに検討した.

\section{I . 対象と方法}

当院に通院している血液透析患者 173 例を対象と し, baPWV 值のレトロスペクティブな検討を行った. 論文へのデータの使用にあたっては，各症例に個人情 報の保護について口頭で説明し，同意を得た。

対象患者の背景を表 1 に，方法を以下に示す.

i ）平成 22 年に測定された背景別 baPWV 值

ii ） EPA-E 投与群と非投与群の baPWV 值の比較 (1 年間)

iii） $\mathrm{EPA}-\mathrm{E}$ 投与群と非投与群の baPWV 值の比較 (経年的推移)

EPA-E (エパデール $\left.{ }^{\circledR}\right)$ は原則として $1,800 \mathrm{mg} /$ 日 を継続的に投与した。なお， ii）は調査期間である平 成 16 年から平成 22 年までに baPWV 測定前後 1 年の 值が得られた患者を対象とし， iii）は調査期間中に測 定された baPWV の変化について検討した.

baPWVはオムロンコーリン社製モデル BP203RPE II を用いて測定した。

データは平均值士標準誤差で表記し, 統計解析は背 景因子についてはカイ二乗検定，フィッシャーの正確 確率検定，スチューデントの $t$ 検定を用いて行った. 
表 1 背景

\begin{tabular}{|c|c|c|c|c|}
\hline & 全症例 & $\mathrm{EPA}-\mathrm{E}$ 投与 & EPA-E 非投与 & $\mathrm{P}^{\mathrm{b}}$ \\
\hline 例数 & 173 & 77 & 96 & \\
\hline 年齢（歳） & $67.3 \pm 0.99$ & $68.0 \pm 1.23$ & $66.8 \pm 1.50$ & N.S. \\
\hline 性別（男/女） & $104 / 69$ & $47 / 30$ & $57 / 39$ & N.S. \\
\hline 透析歴 (年) & $6.42 \pm 0.46$ & $7.69 \pm 0.71$ & $5.44 \pm 0.59$ & $<0.05$ \\
\hline 糖尿病 & 75 & 33 & 42 & N.S. \\
\hline 脳血管疾患 & 18 & 6 & 12 & N.S. \\
\hline 虚血性心疾患 & 29 & 10 & 19 & N.S. \\
\hline 高血圧 & 82 & 42 & 40 & N.S. \\
\hline 喫煙 & 26 & 17 & 9 & $<0.05$ \\
\hline \multicolumn{5}{|l|}{ 併用薬 } \\
\hline 抗血小板薬 & 47 & 21 & 26 & N.S. \\
\hline スタチン & 9 & 3 & 6 & N.S. \\
\hline スタチン・ EPA-E 以外の高脂血症治療薬 & 1 & 1 & 0 & N.S. \\
\hline $\mathrm{Ca}$ 拮抗薬 & 60 & 21 & 39 & N.S. \\
\hline $\mathrm{ARB}$ & 92 & 39 & 53 & N.S. \\
\hline ACE 阻害薬 & 3 & 1 & 2 & N.S. \\
\hline$\alpha$ 遮断薬 & 31 & 13 & 18 & N.S. \\
\hline$\beta$ 遮断薬 & 26 & 13 & 13 & N.S. \\
\hline 利尿薬 & 28 & 16 & 12 & N.S. \\
\hline $\mathrm{LDL}-\mathrm{c}(\mathrm{mg} / \mathrm{dL})^{\mathrm{a}}$ & $85.5 \pm 2.27$ & $82.8 \pm 3.17$ & $87.4 \pm 3.17$ & N.S. \\
\hline $\mathrm{baPWV}(\mathrm{cm} / \mathrm{sec})^{\mathrm{a}}$ & $1,862.7 \pm 36.3$ & $1,901.2 \pm 55.1$ & $1,831.8 \pm 48.2$ & N.S. \\
\hline
\end{tabular}

$\mathrm{a}$ ：試験開始時の值. b : EPA-E 投与群と EPA-E 非投与群の間で検定. N. S. : Not Significant

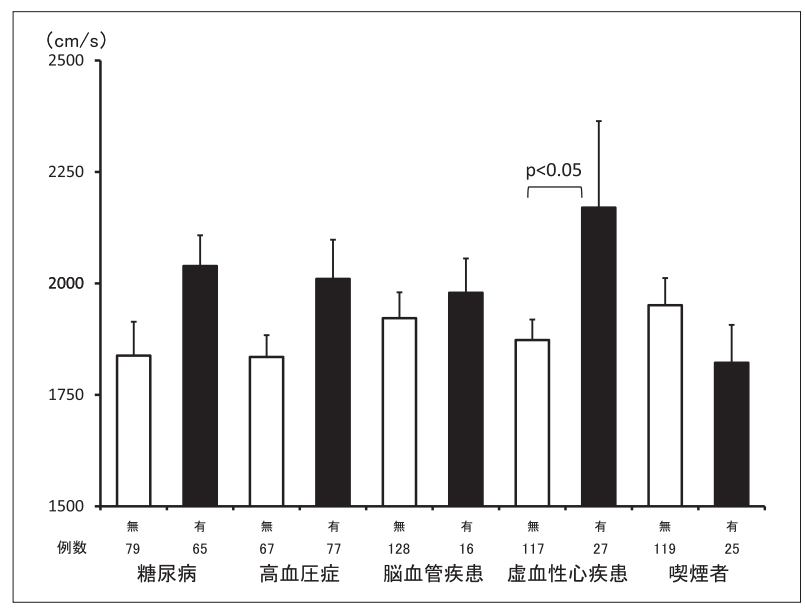

図 1 背景別の baPWV 値

背景別の baPWV 值の比較についてはスチューデント の $t$ 検定を, 経年的な baPWV 值の変化については, 対応のある $t$ 検定抢よび分散分析を用いて行った． 統 計学的有意差は $\mathrm{p}<0.05$ とした。

\section{II. 結 果}

対象患者の平均年齢は $67.3 \pm 0.99$ 歳, 男女比は $104: 69$ であった. 透析歴は平均 $6.42 \pm 0.46$ 年, 各疾 患の合併率は糖尿病 $43.4 \%$, 脳血管疾患 $10.4 \%$, 虚血 性心疾患 $16.8 \%$, 高血圧 $47.4 \%$ であり, 喫煙率は $15.0 \%$ あった. EPA-E 投与群と EPA-E 非投与群

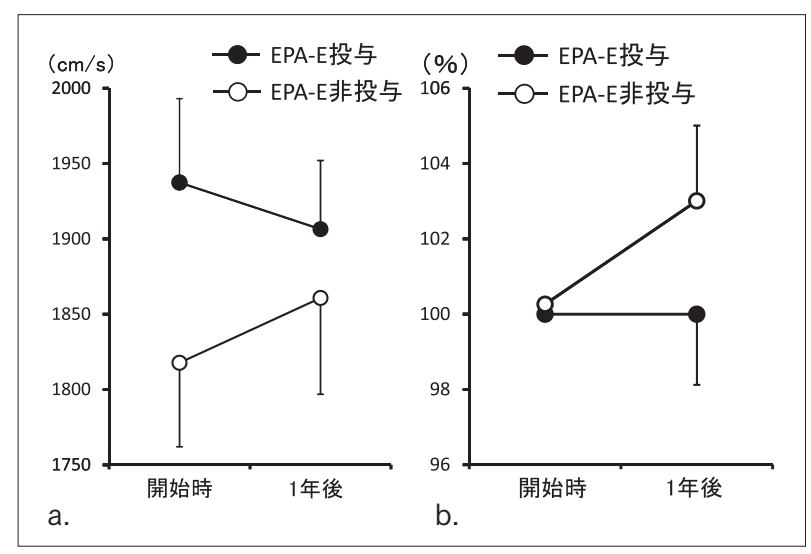

図 $2 a: 1$ 年間の baPWV 値の推移 $\mathrm{b}: 1$ 年間の $\mathrm{baPWV}$ 值の変化率

の間での対象患者の背景の比較では, EPA-E 群で透 析歴が有意に長く，喫煙例が有意に多かったが，その 他の項目において有意差はみられず，また試験開始時 の baPWV 值にも有意差はみられなかった（表 1).

平成 22 年の測定デー夕のある, 血液透析患者 144 例の背景別の baPWV 值を図 1 に示した. 糖尿病非合 併例では $1,838 \pm 76 \mathrm{~cm} / \mathrm{s}$, 糖尿病合併例では $2,039 \pm$ $69 \mathrm{~cm} / \mathrm{s}$, 高血圧非合併例では $1,835 \pm 49 \mathrm{~cm} / \mathrm{s}$, 高血 圧合併例では $2,010 \pm 88 \mathrm{~cm} / \mathrm{s}$, 脳血管疾患非合併例 では $1,922 \pm 58 \mathrm{~cm} / \mathrm{s}$, 脳血管疾患合併例では $1,979 \pm$ $77 \mathrm{~cm} / \mathrm{s}$ であり, 背景として心血管疾患りスクを有す るグループに拈いては, 有さないグループよりも高 


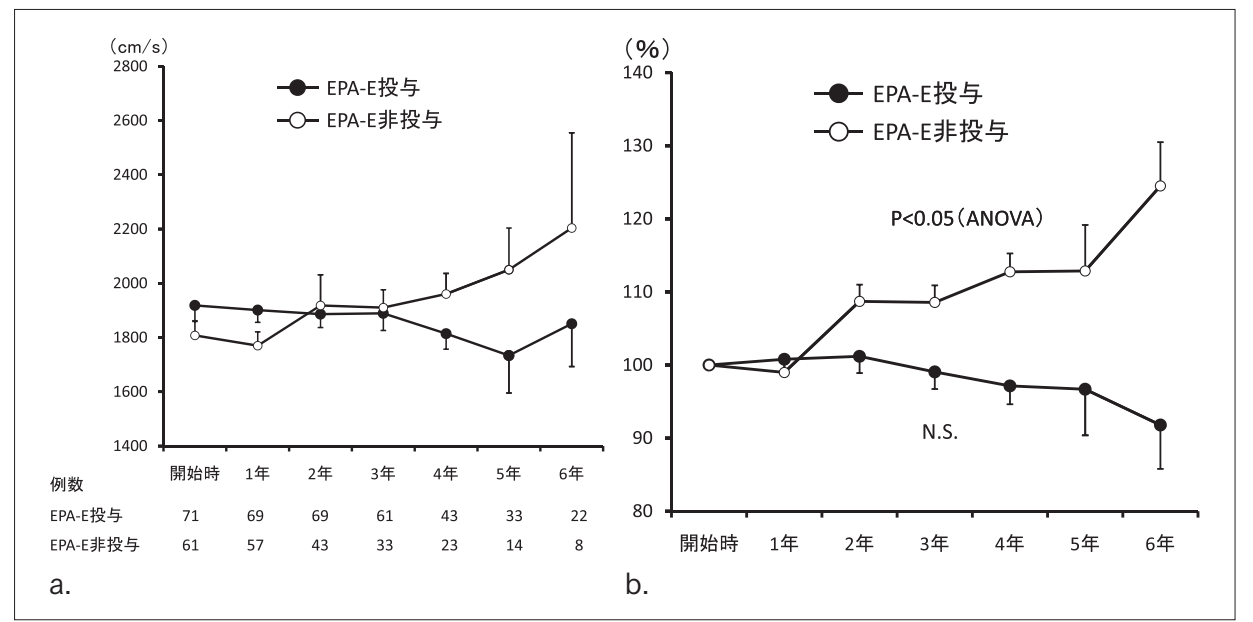

図 $3 a: 6$ 年間の baPWV 值の推移 $\mathrm{b}: 6$ 年間の baPWV 值の変化率の推移

かったが, 統計学的に差は認められなかった。虚血性 心疾患合併例の baPWV 值は $2,170 \pm 194 \mathrm{~cm} / \mathrm{s}$ であ り，非合併例の $1,873 \pm 46 \mathrm{~cm} / \mathrm{s}$ よりも有意に高かっ た．喫煙例では $1,822 \pm 85 \mathrm{~cm} / \mathrm{s}$ ，非契煙例では 1,951 $\pm 61 \mathrm{~cm} / \mathrm{s}$ であり，非喫煙例の方が高かったが，統計 学的に差は認められなかった。

baPWV 測定前後 1 年間のデータが得られた患者は EPA-E 投与群 (70 例), 非投与群（76 例）であり, baPWV 值の変化を図2aに示した。 baPWV 值は $\mathrm{EPA}-\mathrm{E}$ 非投与群において, $1,818 \pm 56 \mathrm{~cm} / \mathrm{s}$ から $1,861 \pm 64 \mathrm{~cm} / \mathrm{s}$ へと上昇したが統計学的に差は認め

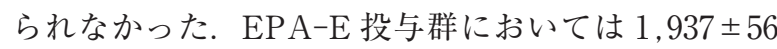
$\mathrm{cm} / \mathrm{s}$ から $1,906 \pm 46 \mathrm{~cm} / \mathrm{s}$ へと低下したが統計学的 に差は認められなかった. 1 年間の baPWV 值の変化 率で比較したところ, 有意差はみられなかったが EPA-E 非投与群では約 3\%の増加がみられた一方,

EPA-E 投与群ではほとんど変化がみられなかった (図 2b).

$\mathrm{baPWV}$ 值の経年的推移は最長 6 年間評価可能で あった。経年的推移においても EPA-E 非投与群では 統計学的に差は認められなかったが上昇し, EPA-E 投与群では変化がみられなかった（図 3a). baPWV 值の変化率の推移においては, EPA-E 非投与群では 有意な上昇がみられた（p<0.05）が， EPA-E 投与群 では有意な変化はみられなかった（図 3b）.

\section{III. 考 察}

透析患者における大動脈 PWV は，健常者よりも高 いことが報告されている. London ら ${ }^{5)}$ は透析患者 92 例と健常対照者 90 例の大動脈 PWV を測定し, 透析
患者では PWVが有意に高いことを示した。また Shoji $5^{7)}$ は非糖尿病血液透析患者 205 名と健常対照 群 184 名の大動脈 PWV を測定し, 各年代で透析患者 の大動脈 PWV が有意に高いことを示した。

透析患者の PWVに影響を与える因子としては糖尿 病 $^{17)}$, 高血圧 ${ }^{18)}$ などが報告されており，脳血管障害や 虚血性心疾患の患者では PWV 值が高いとされてい る ${ }^{19)}$. 今回の検討においてもこれらの背景をもつ患者 においては baPWV が高值であり，特に虚血性心疾患 を合併した症例では baPWV が有意に高值であり，先 の報告に矛盾しない結果が得られた。

今回の検討で喫煙の有無では baPWV 值の平均值に 統計学的な有意差は認められなかったが，非喫煙例の 方が喫煙例よりも高かった。 日本動脈硬化学会による 「動脈硬化性疾患予防ガイドライン 2007」において, 喫煙は動脈硬化性疾患の危険因子とされている一方, 喫煙歴は糖尿病非合併透析患者の大動脈 PWV に有意 な影響を及ぼす因子ではないとする報告もある7)。今 回の検討では喫煙期間を加味していないので，今回の 結果から喫煙の baPWV に与える影響を評価すること は不可能であると考えられる.

今回の対象患者の背景において, EPA-E 群では有 意に喫煙例が多く，透析歴が長かったが， baPWV 值 に有意差はなかったことから，その後の baPWVの変 化を検討する際に影響は少ないと考えられた。

今回の検討において, 経年的な baPWV の変化に対 する EPA-E 投与の影響をレトロスペクティブに評価 したが, 1 年間の baPWV 值の変化率において, EPA$\mathrm{E}$ 非投与群では統計学的に差は認められなかったが上 昇した一方，投与群では変化がみられなかった．また 最長 6 年間の baPWV の変化率の推移において, 
EPA-E 非投与群では有意な上昇がみられたが投与群 では変化がみられなかった。これらの結果より， $\mathrm{EPA}$ は透析患者の動脈硬化の進展を抑制する可能性が示唆 され，その効果は 1 年間という短期的な投与において もある程度みられるが, 数年間にわたる長期的な投与 においてさらに顕著になると考えられた，大動脈 PWV を指標とした透析患者における EPA-E の動脈 硬化の抑制作用については，河野ら ${ }^{15)}$ が EPA-E の 2 年間の投与により, EPA-E 非投与群と比較して PWV の上昇が抑制されたと報告している．今回の検討は baPWV を指標とするレトロスペクティブな検討であ るが，河野らの報告と矛盾しない結果が得られたと考 えられる。

今回の結果にみられる $\mathrm{EPA}$ の抗動脈硬化作用の機 序としては，まず抗血小板作用掞よび抗炎症作用が考 えられる。

EPA は炭素数 20 の $\omega 3$ 系多価不飽和脂肪酸であ る. そのため $\mathrm{EPA}$ と同じ炭素数 20 の $\omega 6$ 系多価不飽 和脂肪酸であるアラキドン酸と, アラキドン酸カス ケードに打いてシクロオキシゲナーゼやリポキシゲ ナーゼを競合する作用を持っている，その結果アラキ ドン酸から産生される血小板凝集作用の強いトロンボ キサン A 2 や白血球活性化能の強いロイコトリエン B4 といったエイコサノイドの産生が抑制され，血小 板凝集作用の弱いトロンボキサン A3 や白血球活性化 能の弱いロイコトリエン B5 の産生が立進し, 抗血小 板作用や抗炎症作用を発揮すると考えられている ${ }^{20)}$. 近年, アラキドン酸カスケードに扔ける競合以外の抗 炎症機序も解明されつつある. EPA は強力な抗炎症 物質であるレゾルビン E1 の供給源となることが見出 され，注目されている。レゾルビン $\mathrm{E} 1$ は $\mathrm{nmol} / \mathrm{L}$ オーダーで皮虐の炎症, 腹膜炎, 樹状細胞の遊走, IL12 の産生を抑制したと報告されている ${ }^{21}$ 。また，マ クロファージやクッパー細胞で発現しており肥満に よって誘導される $G$ 蛋白結合型受容体 GPR120 が, $\mathrm{EPA}$ 等の $\omega 3$ 系多価不飽和脂肪酸のレセプターとし て作用することが発見され，このレセプターを介して 抗炎症作用やインスリン感受性立進作用を発揮する可 能性が示唆されている22).

また, EPAの血清脂質の改善作用も抗動脈硬化作 用の機序であると考えられる. EPA は肝臟において SREBP-1 の発現抑制により, 脂質合成関連酵素の発 現を抑制させ，脂質合成を抑制する。また，PPAR $\alpha$ の発現充進や活性化により,リポ蛋白リパーゼや $\beta$ 酸 化関連酵素の発現を促進させ，脂質消費を充進する. さらに, 構成成分として EPA を取り込んだ VLDLや
LDL は，血中からの消失が速くなり，リポ蛋白のクリ アランスが六進することも報告されている.

その他, 腸管からのトリグリセリドの吸収抑制作用, リポ蛋白リパーゼ活性立進作用 ${ }^{23}$, 血管内皮細胞にお ける接着分子の発現の抑制, 血管平滑筋の遊走の抑制 等多彩な作用が報告されている20).

臨床的には，透析患者に対する $\omega 3$ 系多価不飽和脂 肪酸の投与により，トリグリセリドの低下，レムナン トリポ蛋白や酸化 LDL の低下 ${ }^{24)}$, IL-6 や TNF- $\alpha$ の 低下 ${ }^{25)}$, 酸化ストレスの低下 ${ }^{26)}, \mathrm{CRP}$ の低下 ${ }^{14)}$, ロイコ トリエン B4 の産生抑制 ${ }^{26)}$ がみられたと報告されてい る. EPA はその多彩な作用により, 動脈硬化の進展 を抑制し，透析患者の心血管イベント増加抑制に貢献 できると期待される。

今回の検討においては心血管疾患の発症および死亡 に対する EPA-Eの影響については検討していない が，過去の報告においては， $\omega 3$ 系多価不飽和脂肪酸 の投与が透析患者の心血管イベントを抑制する可能性 が示唆されている. Svensson ら ${ }^{277}$ は心血管病既往の ある透析患者を対象に $\omega 3$ 系多価不飽和脂肪酸を投与 して二次予防効果を検討したところ, 心血管イベント および死亡は抑制されなかったものの，心筋梗塞の発 症は抑制されたと報告している。また JELISにおい て対象は透析患者ではないものの EPA-E の投与によ り冠動脈イベントの発症が抑制されたことが報告され ている ${ }^{11)}$.

透析患者において心血管死亡が多い点については, 3,025 名の透析患者を透析開始から 5 年間追跡した

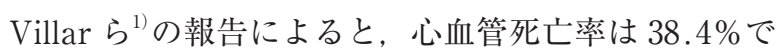
あったとされており，1,846 名の透析患者を平均 2.84 年追跡した Cheung ら ${ }^{2)}$ の報告では心臟死が全死亡の $39.4 \%$ で, 内 $61.5 \%$ が虚血性心疾患であったとされて いる．透析患者の心血管死亡率は年齢，性別，人種， 糖尿病の有無で補正しても，一般住民よりも10２0 倍であるとの報告もある る心血管死亡の割合は健常人と変わらないとの de Jager ${ }^{28}$ の報告もあるが, 全死亡が健常人より 10 倍以 上多いためやはり透析患者の心血管死亡は多いと考元 られる。

この透析患者の心血管死亡と動脈硬化には関連がみ られると考えられ，慢性透析患者では動脈硬化性の心 血管病変による年間死亡率が高いと報告されてい る ${ }^{4)}$ ．心血管イベントと動脈硬化の指標である PWV との関連について，透析患者を対象としたものとして は以下のような報告がなされている. 241 名の透析患 者を平均 72 か月追跡した Blacher $~^{29)}$ の報告におい 
ては, 大動脈 PWV の三分位の最大群は最小群と比較 して全死亡が 5.4 倍, 心血管死が 5.9 倍であった. London $ら^{30)}$ は 180 名の透析患者を平均 52 か月追跡 し, 大動脈 PWV が $1 \mathrm{~m} / \mathrm{s}$ 上がると心血管死が $14 \%$ 増 加すると報告している. Pannier $ら^{31)}$ も 305 名の透析 患者を平均 70 か月追跡した結果, 大動脈 PWV が 1 $\mathrm{m} / \mathrm{s}$ 上がると $12 \%$ 有意に心血管死が増加したと報告 しており，大動脈 PWVが透析患者における心血管イ ベントの発症と関連が深いことが示されている.

今回，われわれが動脈硬化の指標として用いた baPWVは, 大動脈 PWV と異なり, 上腕や下肢の末 梢動脈の脈波伝播速度も含めて測定されている. 上腕 動脈の PWV および大腿動脈の PWV と心血管イベン トとの関連について前述の Pannier らは, 上腕動脈 PWV 単独または大腿動脈 PWV 単独では心血管イべ ントを予測できないと報告している。一方 London ら ${ }^{5)}$ の報告では，年齢および血圧をマッチさせた透析 患者と高血圧患者を比較したところ，透析患者におけ る上腕動脈 PWV および大腿動脈 PWV は高血圧患者 よりも有意に高值であったとされており, baPWVも 心血管イベントの発症と関連があると考えられる.

また，今回の検討はレトロスペクティブな検討であ り，合併症の罹病期間などの影響については十分な情 報が得られず, 解析を行っていない. また, 投与対象 についても，主にbaPWV が高值の患者に EPA-E が 投与されていたが, baPWV 值が高值であっても抗血 小板薬や抗凝固薬が投与されている患者では EPA-E が投与されなかった患者もいた。 今後は対象患者を限 定して，長期的かつ前向きに EPA-Eの baPWVに対 する影響を検討する必要があると考えられる。

\section{結}

\section{語}

年次的に baPWV を測定している血液透析患者 173 例を対象に，患者背景別の baPWV 值および EPA 投 与有無別の経年的な baPWV 值の推移を最長 6 年間に わたり検討した。

患者背景別の baPWV 值は，糖尿病または高血圧合 併例, 脳血管疾患合併例において統計学的に差は認め られなかったが高值であり，虚血性心疾患合併例にお いては有意に高かった。

最長 6 年間の baPWV の平均值の変化率は, $\mathrm{EPA}-$ $\mathrm{E}$ 非投与群では有意な上昇がみられたが， EPA-E 投 与群では変化がみられなかった。

長期的な EPA-E の投与は, 血液透析患者の baPWV の上昇を抑制し, 透析患者の動脈硬化性疾患
の進展抑制および心血管イベント発症抑制に有益であ ると期待される。

\section{文献}

1) Villar E, Remontet L, Labeeuw M, Ecochard R : Effect of age, gender, and diabetes on excess deathin endstage renal failure. J Am Soc Nephrol 18 : 2125-2134, 2007

2) Cheung AK, Sarnak MJ, Yan G, Berkoben M, Heyka R, Kaufman A, Lewis J, Rocco M, Toto R, Windus D, Ornt D, Levey AS ; HEMO Study Group : Cardiac diseases in maintenance hemodialysis patients : Results of the HEMO Study. Kidney Int $65: 2380-2389,2004$

3) Foley RN, Parfrey PS, Sarnak MJ : Epidemiology of cardiovascular disease in chronic renal disease. J Am Soc Nephrol 9 : S16-S23, 1998

4) Lindner A, Charra B, Sherrard DJ, Scribner BH : Accelerated atherosclerosis in prolonged maintenance hemodialysis. N Engl J Med 290 : 697-701, 1974

5) London GM, Marchais SJ, Safar ME, Genest AF, Guerin AP, Metivier F, Chedid K, London AM : Aortic and large artery compliance in end-stage renal failure. Kidney Int 37 : 137-142, 1990

6) Shinohara K, Shoji T, Tsujimoto Y, Kimoto E, Tahara H, Koyama H, Emoto M, Ishimura E, Miki T, Tabata T, Nishizawa Y : Arterial stiffness in predialysis patients with uremia. Kidney Int $65:$ 936-943, 2004

7) Shoji T, Nishizawa Y, Kawagishi T, Kawasaki K, Taniwaki H, Tabata T, Inoue T, Morii H : Intermediate-density lipoprotein as an independent risk factor for aortic atherosclerosis in hemodialysis patients. J Am Soc Nephrol 9 : 1277-1284, 1998

8) Iso H, Kobayashi M, Ishihara J, Sasaki S, Okada K, Kita Y, Kokubo Y, Tsugane S ; JPHC Study Group : Intake of fish and $\mathrm{n} 3$ fatty acids and risk of coronary heart disease among Japanese: the Japan Public Health Center-Based (JPHC) Study Cohort I. Circulation $113:$ 195-202, 2006

9) GISSI-Prevenzione Investigators : Dietary supplementation with $\mathrm{n}-3$ polyunsaturated fatty acids and vitamin $\mathrm{E}$ after myocardial infarction : results of the GISSI-Prevenzione trial. Lancet 354 : 447-455, 1999

10) Gissi-HF Investigators, Tavazzi L, Maggioni AP, Marchioli R, Barlera S, Franzosi MG, Latini R, Lucci D, Nicolosi GL, Porcu M, Tognoni G : Effect of n-3 polyunsaturated fatty acids in patients with chronic heart failure (the GISSI-HF trial) : a randomised, double-blind, placebo-controlled trial. Lancet 372 : 1223-1230, 2008

11) Yokoyama M, Origasa H, Matsuzaki M, Matsuzawa $Y$, Saito Y, Ishikawa Y, Oikawa S, Sasaki J, Hishida H, Itakura H, Kita T, Kitabatake A, Nakaya N, Sakata T, 
Shimada K, Shirato K ; Japan EPA lipid intervention study (JELIS) Investigators : Effects of eicosapentaenoic acid on major coronary events in hypercholesterolaemic patients (JELIS) : a randomised open-label, blinded endpoint analysis. Lancet 369:1090-1098, 2007

12) Ishikawa Y, Yokoyama M, Saito Y, Matsuzaki M, Origasa H, Oikawa S, Sasaki J, Hishida H, Itakura H, Kita T, Kitabatake A, Nakaya N, Sakata T, Shimada K, Shirato K, Matsuzawa Y ; JELIS Investigators : Preventive effects of eicosapentaenoic acid on coronary artery disease in patients with peripheral artery disease. Circ J 74 : 1451-1457, 2010

13) Sekikawa A, Curb JD, Ueshima H, El-Saed A, Kadowaki T, Abbott RD, Evans RW, Rodriguez BL, Okamura T, Sutton-Tyrrell K, Nakamura Y, Masaki K, Edmundowicz D, Kashiwagi A, Willcox BJ, Takamiya T, Mitsunami K, Seto TB, Murata K, White RL, Kuller LH ; ERA JUMP (Electron-Beam Tomography, Risk Factor Assessment Among Japanese and U.S. Men in the Post-World War II Birth Cohort) Study Group: Marine-derived n-3 fatty acids and atherosclerosis in Japanese, Japanese-American, and white men : a cross-sectional study. J Am Coll Cardiol $52: 417-424,2008$

14) Saifullah A, Watkins BA, Saha C, Li Y, Moe SM, Friedman AN : Oral fish oil supplementation raises blood omega -3 levels and lowers $\mathrm{C}$-reactive protein in haemodialysis patients--a pilot study. Nephrol Dial Transplant $22: 3561-3567,2007$

15）河野孝史, 内野順司, 武田稔男, 服部義博, 吉田豊彦, 白井厚治, 斉藤 康：慢性透析患者の大動脈脈波速度 に及ぼすエイコサペンタエン酸エチル（エパデール） の影響. 臨床と研究 $72: 1817-1821,1995$

16）福田祐幹, 庭山 淳, 松沢 史, 西田英一, 児玉裕子, 池田容子, 代田さつき，小倉三津雄，水橋義和：慢性 透析患者の澒動脈内膜中膜複合体の肥厚度（IMT）に 及ぼす EE-dialyzers と Epadel（EPA）の影響。東京 都衛生局臨床研究報告書 1997 : 99-102, 1999

17) Shoji T, Emoto M, Shinohara K, Kakiya R, Tsujimoto Y, Kishimoto H, Ishimura E, Tabata T, Nishizawa Y : Diabetes mellitus, aortic stiffness, and cardiovascular mortality in end-stage renal disease. J Am Soc Nephrol $12:$ 2117-2124, 2001

18) Blacher J, Demuth K, Guerin AP, Safar ME, Moatti N, London GM : Influence of biochemical alterations on arterial stiffness in patients with end-stage renal disease. Arterioscler Thromb Vasc Biol 18 : 535-541, 1998

19）長谷川元治：脈波速度法（PWV）による動脈硬化度の 評価. 日本臨牀 $55 ： 688-690,1997$

20）金 秀植，横山光宏：薬物療法としての多価不飽和脂
肪酸．治療学 $43: 871-873,2009$

21) Arita M, Bianchini F, Aliberti J, Sher A, Chiang N, Hong S, Yang R, Petasis NA, Serhan CN : Stereochemical assignment, antiinflammatory properties, and receptor for the omega-3 lipid mediator resolvin E1. J Exp Med 201 : 713-722, 2005

22) Oh DY, Talukdar S, Bae EJ, Imamura T, Morinaga $H$, Fan W, Li P, Lu WJ, Watkins SM, Olefsky JM : GPR120 is an omega-3 fatty acid receptor mediating potent anti-inflammatory and insulin-sensitizing effects. Cell $142: 687-698,2010$

23）山崎眞利, 長南安浩: イコサペント酸エチル (エパデー ル $\left.{ }^{\circledR}\right)$ と中性脂肪代謝。細胞 $33 ： 314-318,2001$

24) Ando M, Sanaka T, Nihei H : Eicosapentanoic acid reduces plasma levels of remnant lipoproteins and prevents in vivo peroxidation of LDL in dialysis patients. J Am Soc Nephrol 10 : 2177-2184, 1999

25) Rasic-Milutinovic Z, Perunicic G, Pljesa S, Gluvic Z, Sobajic S, Djuric I, Ristic D : Effects of N-3 PUFAs supplementation on insulin resistance and inflammatory biomarkers in hemodialysis patients. Renal Failure $29: 321-329,2007$

26) Taccone-Gallucci M, Manca-di-Villahermosa S, Battistini L, Stuffler RG, Tedesco M, Maccarrone M : N-3 PUFAs reduce oxidative stress in ESRD patients on maintenance HD by inhibiting 5-lipoxygenase activity. Kidney Int $69:$ 1450-1454, 2006

27) Svensson M, Schmidt EB, Jørgensen KA, Christensen JH ; OPACH Study Group : N-3 fatty acids as secondary prevention against cardiovascular events in patients who undergo chronic hemodialysis : a randomized, placebo-controlled intervention trial. Clin J Am Soc Nephrol 1 : 780-786, 2006

28) de Jager DJ, Grootendorst DC, Jager KJ, van Dijk PC, Tomas LM, Ansell D, Collart F, Finne P, Heaf JG, De Meester J, Wetzels JF, Rosendaal FR, Dekker FW : Cardiovascular and noncardiovascular mortality among patients starting dialysis. JAMA 302 : 17821789, 2009

29) Blacher J, Guerin AP, Pannier B, Marchais SJ, Safar ME, London GM : Impact of aortic stiffness on survival in end-stage renal disease. Circulation 11 : 2434-2439, 1999

30) London GM, Blacher J, Pannier B, Guérin AP, Marchais SJ, Safar ME : Arterial wave reflections and survival in end-stage renal failure. Hypertension 38 : 434-438, 2001

31) Pannier B, Guérin AP, Marchais SJ, Safar ME, London GM : Stiffness of capacitive and conduit arteries : prognostic significance for end-stage renal disease patients. Hypertension 45 : 592-596, 2005 